\title{
Pembatalan Akta Pengikatan Jual Beli Yang Dibuat Di Hadapan Notaris Karena Wanprestasi
}

\section{Fitriasih}

Magister Kenotariatan Fakultas Hukum Universitas Islam Indonesia Yogyakarta Indonesia Jln. Cik Di Tiro No. 1 Yogyakarta Indonesia fitriatria9917@gmail.com

Key Word: $\begin{aligned} & \text { Abstract } \\ & \text { Deed cancellation, } \\ & \text { judge decision, }\end{aligned}$ drawn up before a notary is a valid agreement between PT Bantul Kota Mandiri and
justice
PT Rumah Cerdas. As a result of the defendant's actions of not paying off the
payment or default and having been reprimanded by the plaintiff to make the
payment, the plaintiff filed a lawsuit for cancellation of the agreement at the Bantul
District Court. The formulation of the problem in this study is first, what is the
basis for the consideration of the Bantul District Court judge in canceling the sale
and purchase binding deed made before a notary due to default? Second, what are
the legal consequences of canceling the sale and purchase binding deed made before a
notary because of a default? This type of research is normative juridical using two
approaches, namely the statutory and the case approaches. There are 2 (two)
conclusions, first, the decision to cancel the sale and purchase binding deed between
PT Bantul Kota Mandiri and PT Rumah Cerdas is correct from a philosophical,
juridical and sociological aspect and from a justice perspective it has fulfilled legal
justice, social justice and moral justice. Second, due to the decision to cancel the sale
and purchase binding deed, the deed has no legal force, cannot be used as evidence
and the parties' rights are returned as before the agreement

\section{Kata-kata Kunci:}

Keadilan,

Pembatalan Akta, Putusan Hakim

\begin{abstract}
Abstrak
Akta pengikatan jual beli nomor 53 tertanggal 27 November 2013 yang dibuat dihadapan notaris merupakan perjanjian yang sah antara PT Bantul Kota Mandiri dan PT Rumah Cerdas. Akibat perbuatan tergugat yang tidak melunasi pembayaran atau wanprestasi dan telah ditegur oleh penggugat untuk melakukan pembayaran sehingga penggugat mengajukan gugatan pembatalan perjanjian di Pengadilan Negeri Bantul. Adapun rumusan masalah dalam penelitian ini adalah, pertama, apakah dasar pertimbangan hakim Pengadilan Negeri Bantul dalam pembatalan akta pengikatan jual beli yang dibuat di hadapan notaris karena wanprestasi sudah tepat ? Kedua, bagaimanakah akibat hukum pembatalan akta pengikatan jual beli yang dibuat di hadapan notaris karena wanprestasi? Jenis penelitian ini adalah yuridis normatif dengan menggunakan dua pendekatan yaitu pendekatan perundangundangan dan pendekatan kasus. Terdapat 2 (dua) kesimpulan bahwa, pertama, putusan pembatalan akta pengikatan jual beli antara PT Bantul Kota Mandiri dan PT Rumah Cerdas sudah tepat dilihat dari aspek filosofis, yuridis dan sosiologis serta dari sisi keadilan telah memenuhi legal justice, social justice dan moral justice. Kedua, akibat putusan pembatalan akta pengikatan jual beli maka akta tersebut tidak memiliki kekuatan hukum, tidak dapat dijadikan alat bukti dan para pihak hak-haknya dikembalikan seperti sebelum ada perjanjian
\end{abstract}

\section{Pendahuluan}

Dalam Pasal 1313 Kitab Undang-Undang Hukum Perdata (KUHPerdata) ditentukan bahwa suatu perjanjian adalah suatu perbuatan dengan mana satu orang atau 
lebih mengikatkan dirinya terhadap satu orang lain atau lebih. Setiap orang bebas melakukan perjanjian mengenai apapun dan dengan siapapun yang dikehendakinya, termasuk bebas menentukan pelaksanaannya dan syarat-syaratnya, sesuai ketentuan Pasal 1338 ayat (1) KUHPerdata. Perjanjian pengikatan jual beli hak atas tanah dibuat oleh para pihak di hadapan notaris, karena para pihak belum bisa memenuhi syarat atau dokumen-dokumen untuk membuat akta jual beli hak atas tanah (AJB) dihadapan Pejabat Pembuat Akta Tanah (PPAT).

Para pihak dalam perjanjian pengikatan jual beli hak atas tanah tersebut pada mulanya memiliki itikad yang baik, namun terkadang salah satu pihak tidak dapat memenuhi kewajibannya atau prestasinya. Prestasi adalah pemenuhan kewajibankewajiban yang timbul dari hubungan perjanjian. ${ }^{1}$ Menurut Sri Soedewi Maschoen Sofwan, tidak terpenuhinya kewajiban itu ada dua kemungkinan yaitu, karena kesalahan debitor, baik karena kesengajaan maupun karena kelalaian, dan karena keadaan memaksa (force majeure, overmacht), sesuatu yang terjadi diluar kemampuan debitor, debitor tidak bersalah. ${ }^{2}$

Tim Likuidator PT Bantul Kota Mandiri (penggugat) megajukan gugatan ke Pengadilan Negeri Bantul untuk menyatakan bahwa Direktur Utama PT Rumah Cerdas (tergugat) telah wanprestasi atas Akta Perikatan Jual Beli Nomor 53 dan untuk menyatakan bahwa akta tersebut batal demi hukum. Dalam Akta Perikatan Jual Beli Nomor 53 tersebut, Tim Likuidator PT. Bantul Kota Mandiri adalah pihak penjual dan Direktur Utama PT Rumah Cerdas adalah pihak pembeli. Pengadilan Negeri Bantul melalui Putusan Nomor 65/Pdt.G/2015/PN.Btl menyatakan Direktur Utama PT Rumah Cerdas (tergugat) telah ingkar janji atau wanprestasi dan menyatakan batal atas Akta Perikatan Jual Beli Nomor 53 tersebut. Direktur Utama PT Rumah Cerdas (tergugat) tidak puas dengan putusan pengadilan Negeri Bantul kemudian mengajukan banding ke Pengadilan Tinggi Yogyakarta namun Pengadilan Tinggi melalui putusan Nomor 45/PDT/2016/PT.YYK menguatkan Putusan Pengadilan Negeri Bantul. Tidak puas dengan putusan Pengadilan Tinggi Yogyakarta, Direktur Utama PT Rumah Cerdas mengajukan kasasi ke Mahkamah Agung, dan melalui putusan Nomor 371 K/Pdt/2017 Mahkamah Agung menolak kasasi tersebut.

Dari hal tersebut penulis ingin mengetahui lebih lanjut mengenai pembatalan akta pengikatan jual beli dalam permasalahan tersebut, apakah dasar pertimbangan hakim Pengadilan Negeri Bantul sudah tepat dalam pembatalan akta pengikatan jual beli yang dibuat di hadapan notaris karena wanprestasi sdan bagaimanakah akibat hukum pembatalan akta pengikatan jual beli yang dibuat di hadapan notaris karena wanprestasi.

1 Suhendro, Tumpang Tindih Pemahaman Wanprestasi Dan Perbuatan Melawan Hukum Dalam Wacana Akademik Dan Praktik Yudisial, UII Press, Yogyakarta, 2014, hlm. 87.

${ }^{2}$ Ibid., hlm. 88. 


\section{Rumusan Masalah}

Berdasarkan uraian di atas, terdapat dua rumusan permasalahan yakni, pertama, apakah dasar pertimbangan hakim dalam Putusan Pengadilan Negeri Bantul Nomor 65/Pdt.G/2015/PN.Btl sudah tepat dalam pembatalan akta pengikatan jual beli yang dibuat di hadapan notaris karena wanprestasi. Kedua, bagaimanakah akibat hukum pembatalan akta pengikatan jual beli yang dibuat di hadapan notaris karena wanprestasi?

\section{Tujuan Penelitian}

Berdasarkan uraian permasalahan di atas, terdapat dua tujuan penelitian ini yakni, pertama, untuk mengkaji dan menganalisis ketepatan dasar pertimbangan hakim dalam Putusan Pengadilan Negeri Bantul Nomor 65/Pdt.G/2015/PN.Btl. terkait pembatalan akta pengikatan jual beli yang dibuat di hadapan notaris karena wanprestasi. Kedua, untuk menganalisis akibat hukum pembatalan akta pengikatan jual beli yang dibuat di hadapan notaris karena wanprestasi.

\section{Metode Penelitian}

Tipe penelitian ini adalah yuridis normatif dengan menggunakan dua pendekatan, yaitu pendekatan perundang-undangan (statute approach) dan pendekatan kasus (case approach). Pendekatan perundang-undangan dilakukan dengan menelaah semua undangundang dan regulasi yang bersangkut paut dengan masalah hukum yang sedang ditangani sedangkan pendekatan kasus dilakukan dengan cara melakukan telaah terhadap kasus yang berkaitan dengan masalah yang dihadapi yang telah menjadi putusan pengadilan dengan kekuatan hukum yang tetap. ${ }^{3}$ Bahan hukum dalam penelitian ini terdiri dari bahan hukum primer berupa Kitab Undang-Undang Hukum Perdata, Herzien Inlandsch Reglement (H.I.R.), dan Rechtsreglemet voor de Buitengewesten (R.Bg.). Bahan Hukum Sekunder berupa buku, jurnal, dan pidato yang berkaitan dengan topik penelitian ini. Cara pengumpulan data menggunakan studi dokumen dan studi pustaka. Penelitian ini menggunakan analisis deskriptif.

\section{Hasil Penelitian dan Pembahasan}

\section{Ketepatan Dasar Pertimbangan Hakim Pengadilan Negeri Bantul dalam Putusan Nomor 65/Pdt.G/2015/PN.Btl.}

Untuk menganalisis apakah putusan majelis hakim dalam Putusan Nomor 65/Pdt.G/2015/PN.Btl sudah tepat, penulis akan menganalisis berdasarkan hukum dan keadilan. Menurut Bagir Manan, terdapat 3 dasar agar hukum mempunyai kekuatan berlaku dengan baik yaitu memiliki dasar yuridis, sosiologis dan filosofis. ${ }^{4}$ Mengenai dasar berlaku secara yuridis untuk putusan hakim, maka,

1. Hakim memiliki kewenangan memutus suatu perkara;

\footnotetext{
3 M. Syamsudin, Operasionalisasi Penelitian Hukum, Rajagrafindo Perkasa, Jakarta, 2007, hlm. 58.

${ }^{4}$ Bagir Manan, Dasar-dasar Perundang-undangan Indonesia, Ind-Hill.Co, Jakarta, 1992, hlm. 17.
} 
2. Hakim melakukan penyesuaian atau interpretasi hukum berdasarkan jenis dan bentuk peraturan dengan materi persidangan;

3. Hakim memenuhi prosedur dan tata cara yang tertib dalam membuat putusan;

4. Dalam membuat putusan hakim tidak boleh bertentangan dengan peraturan yang lebih tinggi dan sumber segala sumber hukum di indonesia yaitu Undang-Undang Dasar 1945 dan Pancasila.

Dasar berlaku secara sosiologis berarti bahwa putusan hakim harus mencerminkan kenyataan hidup dalam masyarakat baik berupa kebutuhan, tuntutan, atau masalah yang dihadapi. Sedangkan, dasar berlaku secara filosofis adalah menemukan nilai keadilan yang ada di dalam masyarakat. Setiap masyarakat memiliki cita hukum yaitu apa yang diharapkan dari hukum misalnya untuk menjamin keadilan, ketertiban, dan kesejahteraan yang kesemuanya itu dibebankan kepada hakim. Hukum termasuk putusan hakim harus mencerminkan cita hukum tersebut baik sebagai sarana melindungi nilai-nilai maupun sebagai sarana mewujudkannya dalam tingkah laku masyarakat.

Putusan hakim yang mencerminkan cita hukum terlihat pada pertimbangan hukumnya. Pertimbangan hukum putusan mencerminkan kedalaman putusan yang sarat dengan asas, teori, dan argumentasi hukumnya. Keadilan merupakan titik sentral dalam putusan hakim. Namun, tidak mudah untuk menerjemahkan keadilan dalam putusan hakim, apakah mengandung keadilan prosedural yakni keadilan yang didasarkan pada undang-undang atau mengandung keadilan yang sebenarnya (substansial) yakni keadilan yang sebenarnya. ${ }^{5}$

Dalam konteks putusan hakim, peradilan berupa keadilan prosedural (procedural justice) dan keadilan substantif (substantif justice), Bambang Sutiyoso memberikan pengertian keadilan prosedural adalah keadilan yang didasarkan pada ketentuanketentuan yang dirumuskan dari peraturan hukum formal. Keadilan substantif adalah keadilan yang didasarkan pada nilai-nilai yang lahir dari sumber-sumber hukum yang responsif sesuai hati nurani. ${ }^{6}$

Perbedaan konsep keadilan prosedural dan keadilan substansial diungkapkan oleh M.Syamsudin dengan diberikan batasan yang mencantumkan indikator-indikator tertentu berdasarkan peraturan perundangan dan hukum yang berkeadilan. Dari konsep keadilan prosedural, indikator yang digunakan adalah apakah putusan hakim tersebut telah mengikuti prosedur hukum acara secara tepat. Kriteria tersebut yakni:

1. Apakah putusan hakim tersebut sudah memuat hal-hal yang harus ada dalam suatu putusan pengadilan sebagaimana ditetapkan dalam Pasal 2 ayat (1) Undang-Undang No 48 Tahun 2009 dan Pasal 184 HIR/195 RBG. Hal itu meliputi: (a). Kepala putusan; (b). Identitas para pihak; (c). Ringkasan nyata gugatan \& jawaban; (d). Alasan atau pertimbangan hakim dalam putusan; (e). Amar putusan; (f) Hari/tanggal musyawarah dan pembacaan putusan; (g). Biaya perkara.

\footnotetext{
${ }^{5}$ Esmi Warassih Pudjirahayu, Pemberdayaan Masyarakat dalam Mewnjudkan Tujuan Hukum dan Persoalan Keadilan, Pidato Pengukuhan Guru Besar FH Undip, Semarang, 14 April 2001, hlm. 17-18.

${ }^{6}$ Bambang Sutiyoso, "Mencari Format Ideal Keadilan Putusan Dalam Peradilan", Jurnal Hukum No. 2, Volume 17, April 2010), hlm. 227.
} 
2. Apakah putusan hakim tersebut sudah mencermati alat-alat bukti yang sah sesuai dengan Pasal 164, 153, dan 154 HIR atau 284, 180, dan 181 RBG yang digunakan dalam putusan hakim PN mencakup: a. Surat, b. Saksi, c. Persangkaan, d, pengakuan, e, sumpah, f. Pemeriksaan setempat, g. Keterangan ahli.

3. Apakah hakim telah menggunakan alat bukti tambahan.

4. Apakah penerapan hukum pembuktian sesuai dengan perjanjian/undangundang, doktrin dan atau yurisprudensi.

5. Apakah hakim sudah memuat secara proporsional antara argumen penggugat dan tergugat didalam pertimbangannya.

6. Apakah hari tanggal dilakukan musyawarah dan putusan majelis hakim diucapkan telah dimuat.

Sedangkan, untuk konsep keadilan substantif, indikator yang digunakan adalah;

1. Apakah putusan hakim telah dapat membuktikan unsur yang digugat (terkait dengan hukum materiil).

2. Apakah putusan hakim telah mencerminkan penalaran hukum yang logis (runtut dan sistematis).

3. Apakah putusan hakim telah menggali nilai-nilai yang hidup dalam masyarakat (aspek non yuridis).

4. Apakah hakim telah berlaku profesional dalam penyelesaian perkara. ${ }^{7}$

Dikaitkan dengan kriteria di atas, berdasarkan data atau informasi yang terdapat dalam isi Putusan Pengadilan Negeri Bantul Nomor 65/Pdt.G/2015/PN.Btl. dan hasil penggalian data berdasarkan wawancara dapat dikemukakan hal-hal sebagai berikut ini. Mengenai aspek putusan hakim memuat hal-hal yang harus ada dalam suatu putusan pengadilan sebagaimana ditetapkan dalam Pasal 2 ayat (1) Undang-Undang Nomor 48 Tahun 2009 tentang Kekuasaan Kehakiman (UU Nomor 48 Tahun 2009) dan Pasal 184 HIR/195 RBG, isi putusan menunjukkan sudah terpenuhinya unsur-unsur yang harus termuat dalam Pasal 2 ayat (1) UU Nomor 48 Tahun 2009 dan pasal 184 HIR/195 RBG, yaitu:

a. Kepala putusan tertulis "DEMI KEADILAN BERDASARKAN KETUHANAN YANG MAHA ESA".

b. Identitas para pihak yaitu, (1) Tuan Ir. H. Heru Suhadi; (2) Tuan Andhy Soelistyo, S.H., M.Hum; (3) Tuan Drs. Helmi Jamharis, M.M.; (4) Tuan Ir. Eddy Prastono; (5) Nyonya Yossy Covalina semuanya bertindak dan atas nama serta mewakili kepentingan hukum Tim Likuidator PT Bantul Kota Mandiri sebagai para penggugat dan Direktur Utama PT Rumah Cerdas sebagai tergugat.

c. Ringkasan nyata gugatan \& jawaban sebagaimana tercantum dalam pertimbangan putusan halaman 2 sampai 26.

d. Alasan atau pertimbangan hakim dalam putusan sudah tercantumkan dalam putusan halaman 40 sampai 59.

e. Amar putusan sudah dicantumkan dalam putusan halaman 59.

f. Hari/tanggal musyawarah Majelis Hakim, Selasa tanggal 23 Februari 2016 dan pada hari Kamis, tanggal 3 Maret 2016 pembacaan putusan dalam sidang yang terbuka untuk umum juga sudah dicantumkan;

${ }^{7}$ M. Syamsudin, "Keadilan Substantif Yang Terabaikan Dalam Sengketa Sita Jaminan”, Jurnal Yudisial, Vol.5 No.1, April 2012, hlm 36 - 50. 
g. Biaya perkara sudah dicantumkan sebesar Rp. 720.000,- (tujuh ratus dua puluh ribu rupiah).

Dari putusan hakim a quo, sudah terlihat jelas mencermati alat bukti yang sah yang diajukan para pihak yaitu pihak penggugat dan pihak tergugat. Sementara, putusan majelis hakim tidak mempertimbangkan alat bukti tambahan karena pihak penggugat dan pihak tergugat tidak mengajukan alat bukti tambahan. Berkaitan dengan penerapan hukum pembuktian, pun sudah sesuai dengan perjanjian/undang-undang, doktrin dan atau yurisprudensi sebagaimana terlihat dalam pertimbangan hakim merujuk ketentuan dalam perjanjian yang dituangkan dalam akta perikatan Nomor 53 tertanggal 27 November 2013, Pasal 1238, 1243, 1320, 1332, 1340, 1491, 1513, 1865 KUHPerdata, Pasal 145 ayat (1) HIR, Pasal 2 ayat (1) Undang-Undang Nomor 13 Tahun 1985 tentang Bea Materai, yurisprudensi Mahkamah Agung, 11 April 1977 Nomor 3909/K/1994, Putusan Mahkamah Agung Nomor 1270 K/PDT/1991.

Hakim dalam putusan a quo pun sudah berupaya menampilkan secara berimbang atau dimuat secara proporsional antara argumen penggugat dan tergugat di dalam pertimbangan hukumnya serta tanggal pembacaan putusan dalam sidang yang terbuka untuk umum juga sudah dicantumkan. Oleh karena itu, putusan hakim tersebut dari aspek yuridis formal atau aspek keadilan prosedural (procedural justice) atau keadilan hukum (legal justice) atau putusan hakim yang menekankan tujuan hukum akan kepastian hukum maka putusan tersebut sudah benar. Putusan hakim menunjukkan sudah terpenuhinya unsur-unsur yang harus termuat dalam Pasal 2 ayat (1) UU No. 48 Tahun 2009 dan Pasal 184 HIR/195 RBG.

Putusan hakim a quo juga mempunyai kekuatan berlaku dengan baik yaitu memiliki dasar yuridis, sosiologis dan filosofis. Putusan hakim tersebut memiliki dasar berlaku secara yuridis karena putusan hakim tersebut diputus oleh majelis hakim yang memiliki kewenangan untuk memeriksa, mengadili dan memutus perkara tersebut. Dalam putusan tersebut, hakim telah melakukan penyesuaian atau interpretasi hukum berdasarkan jenis dan bentuk peraturan dengan materi persidangan. Artinya, antara fakta-fakta yang diungkapkan para pihak tentang adanya perbuatan hukum para pihak yang dituangkan dalam perjanjian perikatan jual beli di depan notaris yaitu Akta Perikatan Jual Beli No. 53 tertanggal 27 November 2013 kemudian terjadinya fakta wanprestasi yang dilakukan oleh tergugat dan hukum yang diterapkan yaitu ketentuan dalam perjanjian tersebut dan undang-undang yang mengatur perjanjian dan wanprestasi. Oleh karena itu, putusan hakim a quo telah memiliki dasar berlaku secara yuridis.

Putusan hakim a quo juga mencerminkan kenyataan hidup dalam masyarakat yang mana sudah menjadi kebutuhan dan tuntutan masyarakat dalam hubungan perdagangan atau bisnis khususnya atau hubungan keperdataan pada umumnya membutuhkan dan menuntut adanya kesungguhan para pihak satu sama lain untuk memenuhi kesepakatan atau perjanjian yang dibuatnya. Oleh karena itu, putusan hakim itu melindungi hal yang dijunjung tinggi oleh masyarakat yaitu penghormatan terhadap sebuah perjanjian yang mereka buat. Dengan demikian, putusan hakim ini diharapkan akan diterima oleh 
masyarakat secara wajar dan akan memiliki daya berlaku yang efektif atau memiliki dasar berlaku secara sosiologis.

Putusan hakim a quo juga sudah memiliki dasar berlaku secara filosofis artinya hakim telah berusaha menemukan nilai keadilan yang ada di dalam masyarakat. Putusan hakim a quo sudah mencerminkan sistem nilai yang menghargai perjanjian yang dibuat oleh para pihak di dalam masyarakat tersebut sehingga hakim telah menetapkan hukum sebagai sarana melindungi nilai-nilai ketaatan suatu perjanjian maupun sebagai sarana mewujudkannya ketaatan terhadap perjanjian dalam tingkah laku masyarakat. Dari uraian analisis di atas putusan hakim a quo dalam pertimbangan hukumnya telah memenuhi tiga aspek keadilan yaitu legal justice (keadilan hukum), social justice (keadilan sosial) dan moral justice (keadilan moral). Dengan demikian, pertimbangan putusan hakim a quo sudah tepat dan benar.

\section{Akibat Hukum Pembatalan Akta Pengikatan Jual Beli yang Dibuat di Hadapan Notaris karena Wanprestasi}

Selanjutnya perlu diuraikan akibat hukum terhadap perjanjian pengikatan jual beli dalam Akta Perikatan Jual Beli No. 53 yang dibuat di hadapan Notaris-PPAT Sugi Sigit Mahanani Ernawanto S.H pada tanggal 27 November 2013, yang dibatalkan melalui Putusan Pengadilan Negeri Bantul Nomor 65/Pdt.G/2015/PN.Btl. karena tergugat dinyatakan wanprestasi. Dalam pasal 1266 KUHPerdata yang menyebutkan,

"syarat batal dianggap selalu dicantumkan dalam persetujuan-persetujuan yang bertimbal balik, manakala salah satu pihak tidak memenuhi kewajibannya. Dalam hal yang demikian persetujuan tidak batal demi hukum, tetapi pembatalan harus dimintakan kepada hakim. Permintaan ini juga harus dilakukan, meskipun syarat batal mengenai tidak dipenuhinya kewajiban dinyatakan di dalam persetujuan. Jika syarat batal dinyatakan dalam persetujuan, hakim adalah leluasa untuk, menurut keadaan, atas permintaan tergugat, memberikan suatu jangka waktu untuk masih juga memenuhi kewajibannya, jangka waktu mana namun tidak boleh lebih dari satu bulan".

Perjanjian pengikatan jual beli dalam Akta Perikatan Jual Beli Nomor 53 karena tergugat wanprestasi dalam perjanjian tersebut, penggugat mengajukan gugatan ke pengadilan dan pengadilan mengabulkan gugatan penggugat dengan membatalkan perjanjian perikatan jual beli tersebut. Dalam hal yang demikian, persetujuan tidak batal demi hukum, tetapi pembatalan yang dimintakan kepada hakim, karena tergugat wanprestasi. Dengan demikian, pembatalan dalam putusan hakim perkara ini adalah batal dalam pengertian dapat dibatalkan (vernietig). Artinya, perjanjian perikatan itu sebelum dijatuhkan putusan pembatalan oleh hakim, masih sebagai perjanjian yang sah dan mengikat para pihak. Perjanjian perikatan itu baru batal dan tidak mengikat atau tidak mempunyai hukum sejak dibatalkan oleh hakim. Jadi pembatalan perikatan jual beli karena wanprestasi oleh putusan hakim adalah sebagaimana suatu perjanjian yang tidak memenuhi syarat subjektif sahnya perjanjian dalam Pasal 1320 KUHPerdata.

Jadi akibat pembatalan perjanjian oleh hakim dalam putusan ini, tidaklah mengembalikan keadaan atau segala suatu secara penuh seperti keadaan semula, melainkan hanya membatalkan perikatan atau perjanjian antara para pihak yang 
mengikatkan diri dalam perjanjian, sedangkan terkait kepentingan pihak ketiga yang terbit akibat perjanjian tersebut tetap harus ditanggung oleh para pihak.

Hal tersebut jelas berbeda dengan batal demi hukum, suatu perjanjian yang dinyatakan batal demi hukum maka perjanjian tersebut sejak semula dianggap tidak pernah ada. ${ }^{8}$ Perjanjian batal demi hukum karena tidak memenuhi syarat objektif perjanjian dalam Pasal 1320 KUHPerdata yaitu suatu hal tertentu dan sebab yang halal. Untuk syarat suatu hal tertentu contohnya dalam Pasal 1332 KUHPerdata ditentukan hanya barang yang dapat diperdagangkan saja yang dapat menjadi objek atau pokok perjanjian. Sebab yang halal ditentukan dalam Pasal 1337 KUHPerdata yaitu perjanjian yang dibuat harus sesuai hukum yang berlaku dan tidak boleh melanggar kesusilaan dan ketertiban umum.

Sebagian para ahli yang menganggap pada praktisnya, perjanjian yang dapat dibatalkan dan perjanjian yang batal demi hukum pada akhirnya memiliki akibat yang sama, yaitu perjanjian-perjanjian tersebut menurut hukum dinilai tidak memiliki efek hukum. ${ }^{9}$ Hal itu sama dengan yang telah diungkapkan oleh J. Satrio bahwa akibat pembatalan berlaku surut, sehingga sesudah pernyataan batal oleh hakim, maka keadaannya menjadi sama dengan yang batal demi hukum. ${ }^{10}$ Pada keadaaan seperti itu, hukum menilai bahwa kondisi dikembalikan mundur ke kondisi semula. Untuk yang telah melakukan prestasi maka dianggap telah terjadi pembayaran yang tidak diwajibkan. Dalam perkara ini pihak penggugat tetap yang berhak atas tanahnya dan pihak tergugat tetap berhak atas pengembalian uang pembayaran yang masih berupa uang muka atau persekot atau uang tanda jadi sejumlah Rp. 50.000.000,00.

Notaris PPAT Sugi Sigit Mahanani Ernawanto telah menyerahkan jaminan sertifikat tanah milik penggugat yang dititipkannya yaitu 66 bidang tanah berikut segala sesuatu yang tumbuh dan tertanam di atasnya tanpa kecuali. Penggugat/Tim Likuidasi PT BPM (dalam likuidasi) juga telah mengirimkan surat kepada tergugat/Direktur Rumah Cerdas 1 April 2015 tentang pengembalian uang tanda jadi tersebut, sebagaimana telah diakui dan dijadikan bukti oleh tergugat.

Akibat hukum Putusan Pengadilan Nomor 65/Pdt.G/2015/PN.Btl maka akta pengikatan jual beli tanah Nomor 53 tersebut tidak mempunyai kekuatan hukum dan tidak dapat dijadikan sebagai alat bukti yang sempurna oleh para pihak. Pihak penggugat (penjual) juga tetap berhak atas tanah miliknya dan tergugat (pembeli) tetap berhak atas pengembalian uang muka yang telah dibayarkan.

Dalam putusan perkara ini, majelis hakim hanya mempertimbangkan dan memutuskan tentang pembatalan perjanjian perikatan jual beli dalam Akta Notaris Nomor 53 tersebut sebagaimana yang dituntut oleh penggugat. Hakim tidak mempertimbangkan dan mengadili tentang akibat hukum terhadap pembatalan tersebut.

${ }^{8}$ Riduan Syahrani, Seluk Beluk dan Asas-Asas Hukum Perdata, PT. Alumni, Bandung, 2006, hlm. 22.

${ }^{9}$ Elly Erawati dan Herlien Budiono, Penjelasan Hukum Tentang Kebatalan Perjanjian, Gramedia, Jakarta, 2010, hlm. 28.

10 J Satrio, Hukum Perikatan, Tentang Hapusnya Perikatan Bagian 2, Citra Aditya Bakti, Bandung, 1996, hlm. 173. 
Penyelesaian perjanjian perikatan jual beli tanah yang dibatalkan oleh hakim diserahkan sepenuhnya pada itikat baik para pihak. Hal ini karena hakim hanya mempertimbangkan dan memutus apa yang diminta oleh para pihak dan hakim tidak boleh memutuskan hal yang tidak diminta oleh para pihak dan tidak boleh memutus melebihi apa yang diminta oleh para pihak sebagaimana diatur dalam Pasal 178 ayat (2) dan (3) HIR dan Pasal 189 ayat (2) dan (3) RBg bahwa hakim harus mengadili seluruh bagian gugatan, tetapi dilarang menjatuhkan putusan atas perkara yang tidak dituntut atau mengabulkan lebih dari pada yang dituntut.

\section{Penutup}

Berdasarkan uraian pembahasan di atas, dapat ditarik dua kesimpulan yaitu, pertama, pertimbangan hukum pembatalan akta perjanjian pengikatan jual beli sudah tepat dan benar karena telah dilakukan penemuan hukum dengan penafsiran yang logis dan runtut dengan analisis hukumnya sudah tepat dari aspek filosofis, aspek yuridis/normatif dan sosiologis serta telah memperhatikan tiga aspek keadilan yaitu legal justice (keadilan hukum), social justice (keadilan sosial) dan moral justice (keadilan moral). Kedua, akibat hukum putusan pembatalan perjanjian dalam akta pengikatan jual beli tanah tersebut yakni, perjanjian pengikatan jual beli batal dan tidak mempunyai kekuatan hukum/mengikat, sejak dibatalkan oleh putusan hakim. Jadi sebelum dibatalkan oleh putusan hakim, perjanjian pengikatan itu adalah sah dan mempunyai kekuatan hukum/mengikat para pihak. Pihak penggugat (penjual) tetap berhak atas tanah miliknya dan tergugat (pembeli) tetap berhak atas pengembalian uang muka yang telah dibayarkan.

Terdapat tiga saran, pertama, untuk penggugat (penjual) yaitu seharusnya sebelum penggugat menjual objek perjanjian pengikatan jual beli tanah tersebut kepada pihak ketiga, penggugat lebih dahulu mengajukan gugatan pada tergugat (pembeli) tentang pembatalan akta pengikatan jual beli ditambah pembayaran ganti kerugian serta tuntutan penyerahan/pengembalian jaminan sertifikat miliknya dari notaris kepada pengadilan negeri. Kedua, untuk notaris, ketentuan bahwa apabila pihak pembeli (tergugat) tidak bisa menyelesaikan kewajibannya sebaiknya dibuat tegas dan sederhana yang melindungi kepentingan penjual misalkan dengan menentukan penjual dapat menjual tanah tersebut kepada pihak lain setelah mengembalikan uang muka pembayaran. Ketiga, untuk hakim sebaiknya dalam putusan dalam sengketa perkara perdata a quo tidak bersifat deklaratoir atau pernyataan hukum misalkan dengan menambah pertimbangan yang memerintahkan pihak penggugat mengembalikan uang panjar dari tergugat dan memerintahkan notaris mengembalikan jaminan sertifikat milik penggugat.

\section{Daftar Pustaka}

\section{Buku}

Erawati, Elly \& Herlien Budiono, Penjelasan Hukum Tentang Kebatalan Perjanjian, Gramedia, Jakarta, 2010.

Manan, Bagir, Dasar-Dasar Perundang-Undangan Indonesia, Ind-Hill.Co, Jakarta, 1992.

Satrio, J. Hukum Perikatan, Perikatan Yang Lahir Dari Perjanjian, PT Citra Aditya Bakti, Bandung, 2001. 
Suhendro, Tumpang Tindih Pemahaman Wanprestasi Dan Perbuatan Melawan Hukum Dalam Wacana Akademik Dan Praktik Yudisial, UII Press, Yogyakarta, 2014.

Syahrani, Riduan, Seluk Beluk dan Asas-Asas Hukum Perdata, PT. Alumni, Bandung, 2006.

Syamsudin, M, Operasionalisasi Penelitian Hukum, Rajagrafindo Perkasa, Jakarta, 2007.

\section{Jurnal}

M. Syamsudin, "Keadilan Substantif Yang Terabaikan Dalam Sengketa Sita Jaminan", Jurnal Yudisial, Vol. 5 No. 1, April 2012.

Bambang Sutiyoso, "Mencari Format Ideal Keadilan Putusan Dalam Peradilan", Jurnal Hukum No. 2, Volume 17, April 2010.

\section{Pidato}

Esmi Warassih Pudjirahayu, "Pemberdayaan Masyarakat dalam Mewujudkan Tujuan Hukum dan Persoalan Keadilan", Pidato Pengukuhan Guru Besar FH Undip, Semarang, 14 April 2001.

\section{Peraturan Perundang-undangan}

Kitab Undang-undang Hukum Perdata.

Herzien Inlandsch Reglement (H.I.R.).

Rechtsreglemet voor de Buitengewesten (R.Bg.).

\section{Putusan Pengadilan}

Putusan Pengadilan Negeri Bantul Nomor 65/PDT.G/2015/PN.Btl.

Pengadilan Pengadilan Tinggi Yogyakarta Nomor 45/PDT/2016/PT.YYK.

Putusan Mahkamah Agung Nomor 371 K/Pdt/2017. 